\title{
Participatory Management in Academic Libraries: A Review
}

Nicholas C. Burckel

\begin{abstract}
Participatory management and its variants have been the subject of much debate in the management literature for more than twenty years. It has attracted the attention of academic librarians only relatively recently. To put the issue in perspective, this article reviews the major contributions to participatory management theory, examines the arguments of library proponents and critics of the theory, and draws some conclusions about its application in libraries.
\end{abstract}

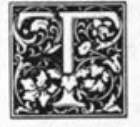

he 1960 s and much of the 1970 s witnessed a meteoric increase in the number of students attending college, partly as a result of the "baby boom" coming of age and partly because a greater proportion of college-age students continued their postsecondary education in colleges and universities. From the 1961-62 to the 1970-71 academic year, college student enrollments grew from 3.9 million to 8.2 million. The growth in the libraries during that same period paralleled this surge. The total number of volumes in university libraries grew from approximately 200 million to some 350 million; the total operating budget jumped from nearly $\$ 184$ million to $\$ 600$ million. Expenditures for library materials increased 370 percent, and the size of library staffs more than doubled from twenty-one thousand to forty-eight thousand. Although less dramatically, the dynamism of the 1960 s extended into the early 1970 s as well. ${ }^{1}$

Even though the growth in library personnel lagged other measurements of library expansion, the increase was impressive. It occurred concurrently with an increased emphasis on proper academic training for professional librarians; the sine qua non even for an entry-level position became the master's degree in library science. This emphasis on formal education, however, simply mirrored the increasingly specialized skills that librarians had to master in order to function competently in a rapidly changing profession. Inevitably the increase in size of academic libraries has meant, as it has in other large and complex organizations, a concomitant increase in the size of the bureaucracies in which librarians work. Among most librarians, "bureaucracy" carries a pejorative connotation, suggesting "isolated levels of organization, impersonal roles for staff members, centralized coordination and decision-making, and rigidly stratified authority and accountability." Organizations so characterized tend to resist change, stifle innovation, and maintain the status quo. ${ }^{2}$

The combination of these elements-an increasing tendency toward bureaucracy and increased professionalism among librarians-has created a tension in the administration of academic libraries. The problem is perhaps more acute on campuses because the obvious role model for academic librarians is the teaching faculty whose organizational style is generally egalitarian and nonbureaucratic. Even if this were not true, librarians could not help but be influenced by the student activism of the 1960 s and early 1970 s, which began as a movement to increase student participation in university governance. In an effort to increase their influence over library policies and procedures, many library staffs sought and gained faculty status; others pushed for changes at variance

Nicholas C. Burckel is associate director of the library/learning center, University of Wisconsin, Parkside. 
with the traditional hierarchical structure of most administrations. Equally concerned administrators experimented with new management techniques in an effort to build morale and effectiveness. ${ }^{3}$

\section{MANAGEMENT THEORIES}

Both staff and administrators turned to management literature to find applicable theory and practice. The oldest management structure, and the one subject to most criticism, was the traditional pyramidal organization with the president or director at the peak of the pyramid and the workers or staff at the base of the organization. Information moved up through successively higher levels of management, and decisions were made at the top, then transmitted down the chain of command for implementation. Except when there were changes at the top, the structure was fairly stable, even static. This management structure evolved naturally as institutions grew and actually predates management theory, which is largely a product of the twentieth century.

Although challenged by a host of experimental alternatives, the traditional structure, with obvious modifications, remains the most common organizational pattern in libraries, perhaps even in academic libraries. ${ }^{4}$

Empirical work designed to make management more a science than an art was pioneered by Frederick W. Taylor; it also tended to reinforce the dominant management tradition. Taylor believed that "scientific management" would assure greater worker productivity, especially in low-skill, mass-production industries. $\mathrm{He}$, therefore, conducted time-andmotion studies at plants and factories to devise ways to make the operation more efficient. This approach sought to make workers as, mechanized and dependable as the machinery they operated. While Taylor felt that the resulting productivity would mean a rising standard of living for the worker, many who applied his techniques merely did so to realize higher profits. Taylor's contribution to future management theory, however, can hardly be overestimated. His research formed the basis for the subsequent evolution of man- agement theory and practice. ${ }^{5}$

Taylor's work remained largely unchallenged during the early decades of the twentieth century, but the research of Elton Mayo at the Hawthorne Works of Western Electric Company between 1927 and 1932 failed to validate predictions based on Taylor's theory. The significance of Mayo's findings lay in the fact that worker productivity was often more affected by social than physical conditions. His major findings varied in nearly every important respect from the principles of scientific management. He concluded:

(1) The level of production is set by social norms, not by physiological capacities. (2) Noneconomic rewards and sanctions significantly affect the behavior of workers and largely limit the effect of economic incentive plans. (3) Often, workers do not act or react as individuals but as members of groups. (4) The function of leadership, both formal and informat, is important in setting and enforcing group norms. (5) Communication between ranks is an important factor in organizational behavior. ${ }^{6}$

Mayo's research contributed to the development of the human-relations school of management based on the study of people as humans rather than work units. Managers turned to the insights of sociologists and psychologists for a better understanding of interpersonal relations. An extension of this school of thought, developed by Douglas McGregor, Rensis Likert, Peter Drucker, and Frederick Herzberg, maintains that "if the organization makes employees happy, it will gain their full cooperation and effort, plus reaching optimum efficiency."'

The concept of participatory management evolved naturally from a cluster of ideas loosely associated with this humanrelations school. Douglas McGregor, for instance, introduced two antipodal management theories $-X$ and $Y$. Theory $X$ assumes that workers avoid responsibility and are lazy, self-centered, and resistant to change; management, therefore, must direct, motivate, and control workers in order to meet organizational goals. Theory $\mathrm{Y}$, on the other hand, makes no negative assumptions about workers, but rather emphasizes that management's major responsibility is "to arrange organi- 
zational conditions and methods of operation so that people can achieve their own goals best by directing their own efforts toward organizational objectives. ${ }^{\prime 8}$

McGregor's work stressed the positive role of workers, given adequate responsibility and freedom; Frederick Herzberg emphasized the difference between "hygiene" factors and motivation factors. The former are factors such as salary, status, working conditions, job security, and interpersonal relationships; the latter include achievement, recognition, work itself, responsibility, and advancement. The absence of some hygienic factors may lead to job dissatisfaction, but their presence does not necessarily guarantee high satisfaction or motivation. Herzberg argues that only factors such as the work itself, responsibility, and advancement have a long-range effect on job attitudes. Thus, high productivity is a reflection of high worker motivation.'

Another major contributor to the human-relations school is Peter Drucker, a widely published management consultant, who has been credited with formulating the much ballyhooed concept of management by objectives (MBO), which actively involves employees in planning and controlling their jobs on the assumption that "such involvement fosters commitment, and that commitment motivates employees to channel their efforts in a way that will effectively contribute to the achievement of organizational objectives." The major components of MBO include goal setting, action plans, periodic reviews, and annual performance appraisal. MBO proponents claim seven benefits: "improvements in management performance, planning, coordination, control, flexibility, superior-subordinate relationships, and personal development." Until recently MBO appeared to be the panacea for business and academic managers alike. ${ }^{10}$

The last major contributor to the human-relations school considered here is Rensis Likert, formerly director of the Institute for Social Research at the University of Michigan. In two highly influential studies, New Patterns of Management and The Human Organization, Likert constructs and elaborates his theory of participatory management. He constructs four organizational models, graduated from system 1 (authoritarian) to system 4 (participative), and argues that the most productive organizations are those that best approximate system 4 . At the heart of participatory management is group decision making, which Likert sees as superior to individual decision making because:

(1) Available cues are increased. (2) The immediacy of feedback regarding suggestions allows faster recognition of potential mistakes. (3) The greater formulation of ideas by people in groups than by people acting separately favors group decisions. (4) The increasing division of labor favors group decisions by utilizing to greater advantage the group's cumulative expertise. (5) There is less inhibition because of personal responsibility for failure. (6) Pooling ideas provides an opportunity for identifying and removing errors. (7) If the group is organized from members who have developed neither friendship nor animosity patterns and if the group retains its identity for only a short time period, the lack of identification of the members as a cohesive group enhances their ability to consider the problem objectively. ${ }^{11}$

\section{PROPONENTS OF PARTICIPATORY MANAGEMENT}

Likert, McGregor, Herzberg, and Drucker, each in his own way, have contributed to the popularity of participatory management. Although much of their work was based on industrial or business models, librarians saw in its application to libraries a solution to the problems of an authoritarian structure, the alienation of professionals, and a numbing bureaucracy. While many librarians extolled the merits of participatory management without fully understanding the implications, a few methodically examined and evaluated library applications of the concept. The most influential and thorough of these studies was undertaken by Maurice P. Marchant in his dissertation, "The Effects of the Decision Making Process and Related Organizational Factors on Alternative Measures of Performance in University Libraries," and then in later articles and a monograph. Marchant recognized that Likert's theory was built on research in profit-making organiza- 
tions, but felt it might as easily apply to nonprofit organizations, and so he tested it in academic libraries. Specifically, Marchant chose twenty-two university or research libraries from which he collected data to measure the relationships between various performance criteria (dependent variables) and the degree of librarian participation in management (independent variable). The five dependent variables were "(1) staff job satisfaction, (2) extent of library long-range planning, (3) uniformity in library evaluation, (4) circulation of materials for home use, and (5) faculty evaluation of library services, facilities, and resources." The study also included thirteen different control variables, such as doctoral degrees granted by the institution, perquisites available to the library staff, and number of professional librarians, which he thought might affect one or more of the dependent variables. Using regression and correlation techniques, he analyzed the data and concluded that "involvement of the university library staff in the library's administration produces greater staff job satisfaction and, through it, better libraries." In particular, participatory management forced decisions to be made at the level best suited for effective resolution, thus freeing top management for long-range planning and cultivating relations with university administrators and key faculty. Moreover, he argued, participatory management helped the staff "unify its value system regarding both the relative importance of various aspects of the library and the quality of those aspects in a given library.'

Marchant's was not the only study of library applications of participatory management. Shortly after Marchant completed his study, Henry Stewart, Jr., conducted a similar study for his doctoral research at Indiana University. Unlike Marchant, however, Stewart examined six small colleges drawn from the Associated Colleges of the Midwest and personally administered the questionnaires. He concluded, as Marchant did, that there was no direct relationship between a library's management style and selected performance characteristics of that library, but that staff morale was affected by managerial style. He further opined that there might be "no relationship between managerial style and productivity in business enterprises where there are fewer than ten employees." ${ }^{13}$

In a less rigorous approach than that of Marchant and Stewart, Jane Flener, with the aid of a fellowship from the Council on Library Resources, traveled to ten re-. search libraries during 1971-72 to examine firsthand the application of management theory in libraries. She found that the degree of staff participation depended not merely "on the attitude and personality of the administration, but also on the dynamism and leadership within the staff." Quite a significant proportion of staff, she observed, did not participate for a variety of reasons-"'some for personal reasons, some for lack of interest, some who did not want to take the time from their duties, and some who philosophically disagreed with the concept." 14

More recently Nancy Brown, University of Guelph Library, developed an operational model for actually measuring staff participation. The three major determinants of participation on which the model is based are "the degree of control over the decision-making process; the issues subject to control; and the hierarchical level at which control is exercised." She also suggested how information on each of these can be obtained. While not applying her model to any institution, she has demonstrated how participation can be measured quantitatively. Her model awaits application by future researchers. ${ }^{15}$

Despite the paucity of rigorous analysis and the inconclusive results of those studies, proponents of participatory management claim much for it. In a discussion of change in academic libraries, for instance, Robert Haro concludes his article with strong endorsement of participatory management:

The opportunities for significantly effecting change, service or organizational, can be considerably enhanced by a participative management approach. Indeed, the extent to which recommendations within a library are likely to be implemented, and innovative ideas generated and acted upon, depends upon the 
amount of participation by individuals committed to the process of change. . . . Participatory management can be made to work in an academic library if improved service is the goal of change.

While Haro's conclusions are plausible, he offers no convincing evidence. ${ }^{16}$

Fidelia Dickinson, California State University, San Diego, in a discussion of libraries in the California State University and College system, assumes at the outset "the merits and general workability of participative management." The major benefits she attributes to participatory management are an increased commitment of staff to the library profession, increased job satisfaction, a reduction of factionalism and territoriality, greater acceptance of decisions, and a higher quality of library staff. In a strident and undocumented article in the same journal two years later, Thomas Gwinup of San Diego State University denounced the traditional bureaucratic structure as having "promoted the detachment of administrators and the disunity of the profession. It has advanced professional incompetence with its politically and clerkishly oriented scheme of rewards." Bemoaning the failure to restrict the number of graduates from library schools, the lack of either a union or an association to protect librarians, and the unresponsive structure of most academic library administrations, he concludes that only participative management offers a realistic solution. ${ }^{17}$

Although examining academic libraries from a different point of view, Duane Webster and Jeffrey Gardner, both of the Association of Research Libraries' Office of University Library Management Studies, find a number of benefits of increased staff participation in library decisions. One benefit, perhaps unintended, of such participation in major library planning is increased staff enthusiasm that may lead to better service for patrons and that also may favorably influence university administrators. Another benefit from staff participation, they argue, is improved staff-management relations, "as staff members learn more about the complex and very difficult processes involved in managing an academic library.",18
In the most recent book-length treatment of the subject, Donald Sager, formerly of the Chicago Public Library, published Participatory Management in Libraries to generally favorable reviews. Sager's is a practitioner's guide, designed to demonstrate how participatory management can alleviate common problems faced by library supervisors and employees. By and large he instructs by example, relegating theoretical aspects of the topic to a selective bibliography. While he writes about participatory management in libraries generally, his techniques are applicable to academic libraries. Because he writes as an advocate, his book is of most help to those planning to implement the theory. It is less useful for those needing a rigorous analysis of the benefits and drawbacks of such an approach. In one of his concluding chapters, for instance, Sager correctly identifies some of the problems associated with participatory management and makes practical suggestions for dealing with them. None of them, however, appears drawn from actual library experience, and the general paucity of documentation throughout leaves the reader without anything but Sager's word on which to rely. As do other advocates, he cites a number of benefits to employers and employees who adopt participatory management-greater creativity and innovation, less job dissatisfaction, and more individual flexibility. He concludes with an observation that the movement toward participatory management in the workplace will continue to grow as political, economic, and social institutions become more democratic. ${ }^{19}$

A number of university libraries have experimented with some degree of participatory management and have declared those efforts a success. After a two-year study of participatory management, the Duke University Librarians' Assembly adopted a set of proposals to increase staff participation in library governance. In California, perhaps the best examples of participatory management in action are at the University of California, Los Angeles, and at California State University, San Diego. The implementation of a wideranging staff participatory systemt appar- 
ently revitalized the staff at Dickinson College's library, where librarians had been "uneasy about the quality of the library and restless about their own roles and self perception in a traditional hierarchical structure." At the University of Guelph, Chief Librarian Margaret Beckman stressed the inappropriateness of the faculty collegial governance model for libraries, arguing instead for a participatory form of management that "can achieve all the benefits of a collegial system and still leave the library director with a role for which he or she can accept accountability. ${ }^{\prime 20}$

\section{CRITICS OF \\ PARTICIPATORY MANAGEMENT}

Given this overwhelming chorus of support for participatory management, one might conclude that it will solve most major management problems. Criticism, however, has been equally strong. Scarcely more than a year after Maurice Marchant's pioneering article appeared in Library Trends, it was critically reviewed by Beverly Lynch. Lynch took issue with nearly every aspect of Marchant's workits theory, methodology, measurement, analysis, and conclusions. Much of the criticism was technical, but its main tenets can be sketched. Marchant readily admitted his debt to the research of Rensis Likert, and Lynch first turned her attention to more recent studies of his theory of participative management and productivity. These recent studies tended to be inconclusive regarding any relationship between participatory management and productivity. She also argued that Marchant adopted Likert's model without verifying its applicability to institutions such as libraries, and then incorrectly adapted it to his own purposes. In concluding her review, Lynch discounted Marchant's study, declaring:

Given the inadequacies of the theoretical development and the invalid measure of decision making . . . the study provides no basis for the generalization that an increase in the library staff's participation in decision making will increase library effectiveness. ${ }^{21}$

In a rejoinder, published immediately following Lynch's article, Marchant pointed out that while subsequent scholarly research of social psychologists has challenged Likert's theory, a significant number of studies have corroborated it. Much of the rest of his article is devoted to a point-by-point refutation of Lynch's specific criticisms. In a subsequent article dealing with organizational structure and the academic library, Lynch returned to Marchant's work to emphasize that what librarians need to know is not so much the relative degree of job satisfaction, but rather what organizational structure will achieve high staff performance. Librarians have to be willing, she contended, to ask the unpopular but important question, "Would more staff participation in decision-making result in lower library effectiveness? That is, the more time the librarians spend on committee work, the less time they spend on professional work, which may lower their effectiveness and thus the library's.",22

The Lynch-Marchant exchange, however, was only the first attack on the benefits of participatory management in libraries. Two articles by former University of Wisconsin Library director Louis Kaplan raised additional questions about participatory management. He cautioned that improperly introducing participatory management can lead to disillusionment. Citing studies made of participation in other organizations, he forecast that "much disappointment will be experienced with participation, largely because of lack of skill and unreal expectations." $\mathrm{He}$ also emphasized the view expressed by a recent study of participation theory that many of the benefits claimed for participation "are subject neither to absolute proof nor disproof, and that no complex organization can ever operate purely on the participatory principle.,"23

Kaplan also suggested a number of cautions in applying Likert's theory. He noted, for instance, that subsequent research has shown that Likert's dichotomy between "authoritative" and "participative" management is too simplistic. Likert also failed to note organizational variables, such as the state of technology, in his scheme. Finally, he omitted individual 
personality differences that might determine whether or not an employee will accept or reject participation. Relying on research findings based on nonlibrary organizations, Kaplan takes issue with Marchant's contention that group decisions will be more readily accepted by the group. Kaplan lists four possible negative results from group decision making:

Individuals whose opinions have been rejected by the group may be alienated; the expectations aroused by group participation lead to further demands that management cannot always satisfy; the process of group decision making may prove frustrating to several in the group; though participation may bring about group cohesiveness, cohesiveness might be turned against, as well as in favor of management.

Another possible source of tension under a participatory system arises, Kaplan contended, over the use of discretion. While regulations and guidelines govern most situations, occasionally good judgment dictates discretion in applying them. In group situations employees might be unwilling to grant necessary exceptions because they do not want to have to make individual judgments; they would prefer instead simply to apply rules without exception. ${ }^{24}$

In a critical overview of management by objectives in academic libraries, James Michalko also offered some caveats applicable to participatory management generally. His review of recent research on worker motivation bears out Kaplan's point that a wide range of variables affects performance. None of the theories Michalko examined, in fact, argued that job satisfaction was a determinant of job performance. He also pointed out that the library could not realistically emulate the regular faculty because the library "is a service organization whose effectiveness depends on the coordination of its members, not their independence." The value of participation depends on whether or not the major organizational goal is staff satisfaction or organizational effectiveness. ${ }^{25}$

Without directly criticizing participatory management, Bruce Bergman discusses a number of elements that contribute to job satisfaction other than direct staff partici- pation in management. These elements, such as the feeling that one's talents are being well used or the satisfaction derived from helping another, have more to do with a librarian's interaction with the public than with the administrative structure of the library. Bergman also noted that much of what the library staff does is dictated by circumstances and conditions outside the library over which neither staff nor library management have direct control. These externalities may be crucial in determining management structure and style. $^{26}$

Although Peter Drucker is properly identified with the human-relations school of management, some of his recent work has been cited in an article critical of participatory management by James F. Govan, former university librarian of the University of North Carolina. While participatory management may be especially appropriate to some organizations, it may have much less utility, Govan noted, for a service organization such as the library. In such service organizations, Drucker has argued, management requires "the control of costs, not performance and results, as in a commercial enterprise." If Drucker is correct, Govan argues, then librarians need to be concerned about committee work, deliberations, and other participatory exercises that may push costs up without a compensating rise in productivity. Participation requires time and money, " and often, like faculty deliberations, produce[s] rather conservative results." He goes so far as to suggest that participatory management may be a luxury libraries cannot afford in a period of declining resources and increased responsibilities.

\section{CONCLUSIONS}

Can any conclusions be reached from this review of the extensive recent literature on participatory management in academic libraries? Certainly one conclusion is that while enthusiasm for participatory management continues, the experience of some institutions and the research of librarians have tempered some of the more extravagant claims of its early proponents. Perhaps in Hegelian fashion, having 
swung between support and criticism of participatory management, librarians are finding a synthesis on which they can agree. No one seriously questions that properly implemented and maintained, participatory management generally increases staff morale and job satisfaction. "Proper implementation" usually means active support for the technique by top library administrators and phased adoption. It also implies that librarians understand the limits of their involvement and that such participation will not solve all library problems or guarantee happiness with all decisions. Conflicts will still arise and difficult decisions will still have to be made. Perhaps another reason for a more cautious approach to participatory management is the realization that it is best suited to periods of affluence and expansion rather than the fiscal stringency and contraction of the 1980s. While many understandably wish to participate in building collections and expanding services, few want to accept the responsibility for reducing hours, eliminating services, or laying off staff. ${ }^{28}$

The evidence of the effect of participatory management on library effectiveness or productivity is inconclusive. Current management literature suggests that staff satisfaction does not necessarily determine effectiveness. Since service organizations are not designed primarily for employees, but rather for patrons or users, librarians need to make sure that participatory management at least does not hamper effective service. While it is generally accepted that participatory management does not reduce costs, no one has yet devised an accurate and sophisticated enough measurement of the actual costs of group decision making. Even if one concedes that group decisions are better in some sense than those of individuals, are they so much better that the additional time and cost associated with the group decisions are offset? ${ }^{29}$

This latter question highlights the central issue underlying much of the debate over participatory management-theory. Rigorous statistical analysis, like that used by Marchant and Lynch, is a powerful tool that librarians must increasingly bend to their use. At the same time, there is a real danger in its improper use. It is a welldeveloped theory of service organization management that will specify the choice of variables and the expected relationships among them. The application of appropriate statistical methods can then be used to test the theory. But since much of the new : methodology and theory will come from. other disciplines, such as social psychology, it will be necessary for librarians to keep abreast of the current research literature. Too often interdisciplinary research proves inadequate because part of it is based on discredited theory. Richard Eggleton, University of North Carolina at Greensboro, summarized the problem of information transfer from management to library literature: "We accept and use second-hand and popularized versions of theory; by the time new insights reach our literature from other disciplines they are years old, and sometimes, even out of favor or greatly changed by the discipline from which they emanate. ${ }^{\prime 30}$

Finally, librarians will have to accept that participatory management is no substitute for individual responsibility and leadership. There will likely always be library directors and just as likely they will be paid considerably more than the rest of the nonadministrative staff. Directors receive such salaries not because they are older, more intelligent, or harder workers than other professionals, but because they are accountable for the operation of the library. It is the director who most often will set the parameters within which staff participation will operate. Librarians, therefore, should seek in their administrators "leadership that seeks consensus which is sound and responsive to present and future needs, but leadership that takes active responsibility for identifying appropriate directions for library development and for the vigorous, aggressive pursuit of clearly defined institutional and client interests." That, in turn, promises the best environment for successful participatory management. ${ }^{31}$ 


\section{REFERENCES}

1. Edward G. Holley, "Organization and Administration of Urban University Libraries," College \& Research Libraries 33:175 (May 1972).

2. Duane Webster and Jeffrey Gardner, "Strategies for Improving the Performance of Academic Libraries," Journal of Academic Librarianship 1:13 (May 1975); Bruce Bergman, "Participatory Management: Some Reservations," Lacuny Journal 4:7 (Spring 1975).

3. Holley, "Organization and Administration," p.175-79; Webster and Gardner, "Strategies for Improving," p.13.

4. Guy L. Lyle, The Administration of the College Library (New York: Wilson, 1974), p.38-39; Robert D. Stueart and John Taylor Eastlick, Library Management (Littleton, Colo.: Libraries Unlimited, 1977), p.15-21.

5. Stueart and Eastlick, Library Management, p.15-21.

-6. Maurice P. Marchant, Participative Management in Academic Libraries (Westport, Conn.: Greenwood Pr., 1976), p.2-3.

7. Stueart and Eastlick, Library Management, p.21-22.

8. Jerrold Orne, "Future Academic Library Administration-Whither or Whether," in Evan Ira Farber and Ruth Walling, eds., The Academic Library: Essays in Honor of Guy R. Lyle (Metchen, N.J.: Scarecrow, 1974), p.82-84.

9. Stueart and Eastlick, Library Management, p.138-41.

10. James Michalko, "Management by Objectives and the Academic Library: A Critical Overview," Library Quarterly 45:235-37 (July 1975); Ernest R. DeProspo, "Management by Objectives: An Approach to Staff Development," in Elizabeth W. Stone, ed., New Directions in Staff Development: Moving from Ideas to Action (Chicago: American Library Assn., 1971), p.39-47; Peter Drucker, "Managing the Public Service Institution," College \& Research Libraries 37:4-14 (Jan. 1976).

11. Rensis Likert, The Human Organization: Its Management and Value (New York: McGraw-Hill, 1976), p.3-46; Marchant, Participative Management, p.5-7.

12. Maurice P. Marchant, "Participative Management as Related to Personnel Development," Library Trends 20:48-59 (July 1971); Marchant, Participative Management, p.6-10, 37-41, 148-65.

13. Henry R. Stewart, Jr., "Staff Participation in the Management of College Libraries and Its Relationship to Library Performance Characteristics," (Ph.D. dissertation, Indiana University, 1972), p.1-5, 107-15.

14. Jane G. Flener, "Staff Participation in Management in Large University Libraries," College $\mathcal{E}$ Research Libraries 34:275-79 (July 1973).

15. Nancy Brown, "Academic Libraries an Operation Model for Participation," Canadian Library Journal 36:201-7 (Aug. 1979).

16. Robert P. Haro, "Change in Academic Libraries," College \& Research Libraries 33:97-103 (Mar. 1972).

17. Fidelia Dickinson, "Participative Management: A Left Fielder's View," California Librarian 34:24-33 (Apr. 1973); Thomas Gwinup, "Participation in Decisions: Reference, the Library, and the Larger Question," California Librarian 36:56-62 (Apr. 1975).

18. Webster and Gardner, "Strategies for Improving," p.13-18.

19. Donald J. Sager, Participatory Management in Libraries (Metuchen, N.J.: Scarecrow, 1982), p.vii-x, 155-79.

20. Library Journal 99:2116-17 (Sept. 15, 1974); Library Journal 100:248 (Feb. 1, 1975); American Libraries 12:605-6; (Nov. 1981); Library Journal 102:321-22 (Feb. 1, 1977).

-21. Beverly P. Lynch, "Participative Management in Relation to Library Effectiveness," College \& Research Libraries 33:382-90 (Sept. 1972).

22. Maurice P. Marchant, "And a Response," College \& Research Libraries 33:391-97 (Sept. 1972); Beverly P. Lynch, "Organizational Structure and the Academic Library," Illinois Librarian 56:201-6 (Mar. 1974).

23. Louis Kaplan, "Participation: Some Basic Considerations on the Theme of Academe," College \& Research Libraries 34:235-41 (Sept. 1973).

24. braries 36:473-79 (Nov. 1975).

25. Michalko, "Management by Objectives," p.239-47.

26. Bergman, "Participatory Management," p.7-9. 
27. James F. Govan, "The Better Mousetrap: External Accountability and Staff Participation," Library Trends 26:255-67 (Fall 1977).

28. Edward R. Johnson and Stuart H. Mann, Organization Development for Academic Libraries: An Evaluation of the Management Review and Analysis Program (Westport, Conn.: Greenwood Pr., 1980), p.149-51; Charles R. McClure, Information for Academic Library Decision Making: The Case for Organizational Information Management (Westport, Conn.: Greenwood Pr., 1980), p.186-88.

29. Govan, "The Better Mousetrap," p.261-64.

30. Richard Eggleton, "Academic Libraries, Participative Management, and Risky Shift," in Robert D. Stueart and Richard D. Johnson, eds., New Horizons for Academic Libraries: Papers Presented at the First National Conference of the Association of College and Research Libraries; Boston, Massachusetts, November 8-11, 1978 (New York: K. G. Saur, 1979), p.96-101.

31. Thomas J. Galvin, "Beyond Survival: Library Management for the Future," Library Journal 101:1833-35 (Sept. 15, 1976). 